\title{
Effect of Agricultural Model of using Fertilizer, Harvesting Time and Extraction Method on Phytochemical Contents and Antioxidant Activities from Mulberry Leaves Grown in Maha Sarakham Province, Thailand
}

\author{
Pharnuwan Chanhan ${ }^{1}$, Ampa Konsue ${ }^{2}$, Rachanee Nammatra ${ }^{3, *}$
}

Pharnuwan Chanhan', Ampa Konsue ${ }^{2}$, Rachanee Nammatra ${ }^{3, *}$

\section{${ }^{1}$ Center of Excellence for Silk Innovation, Mahasarakham University, Maha Sarakham, 44150, THAILAND. \\ ${ }^{2}$ Faculty of Medicine, Thai Traditional Medicine Research Unit, Mahasarakham University, Maha Sarakham, 44000, THAILAND. \\ ${ }^{3}$ Production and Quantity Control of Herbal Tea Laboratory, Biodiversity and Conservation Research Unit, Walai Rukhavej Botanical Research Institute, Mahasarakham University, Maha Sarakham, 44150, THAILAND. \\ Correspondence \\ Dr. Rachanee Nammatra}

Production and Quantity Control of Herbal Tea Laboratory, Biodiversity and Conservation Research Unit, Walai Rukhavej Botanical Research Institute, Mahasarakham University, Maha Sarakham, 44150, THAILAND.

Phone no : +66-61-9965554

E-mail: rachanee.n@msu.ac.th

\section{History}

- Submission Date: 17-12-2018;

- Review completed: 09-01-2019;

- Accepted Date: 12-02-2019

DOI : 10.5530/pj.2019.11.85

Article Available online

http://www.phcogj.com/v11/i3

\section{Copyright}

(c) 2019 Pharmacognosy Journal. This is an open-access article distributed under the terms of the Creative Commons Attribution 4.0 International license.

\begin{abstract}
Aims: Phytochemical contents and free radical scavenging of Mulberry leaf extracts by using different fertilizer, time of harvesting and solvent extraction were evaluated. Materials and Methods: Dried Mulberry leaves were extracted by using different solvent including aqueous, $50 \%$ ethanol and $95 \%$ ethanol. The phytochemical screening were determined by Total Phenolic Compounds (TPC) and Total Flavonoid Contents (TFC). The anti-oxidation were tested by using 2,2-diphenyl-1-picrylhydrazy (DPPH) radical scavenging and 2,2 -azinobis-(3ethylbenzothiazoline-6-sulphonate) (ABTS+) assay. Results: This experimental study found that the mulberry leaf extract were given extraction with $95 \%$ ethanol, all of fertilizer and at Week 4 showed highest total phenolic contents espectcially BET2 was high amount of TPC $(124.444 \pm 0.609 \mathrm{mgGE} / \mathrm{gExt})$. The harvest time, all of groups at the Week 4 were significantly higher than all of groups at the Week 2. On the other hand, total flavonoid contents, the DET1 (Fertilizer formula 15-15-15, extraction with 95\% ethanol at the Week 2; 110.913 \pm 3.208 mgQE/gExt) showed highest amount. The Antioxidant activities, DPPH free radical scavenging activity, The groups were given extraction with 95\% ethanol, all of fertilizer at the Week 4 including $\mathrm{CHT} 2\left(\mathrm{IC} \mathrm{C}_{50}=0.00459 \pm 0.00001 \mathrm{mg} / \mathrm{mL}\right), \mathrm{BHT} 2\left(\mathrm{IC}_{50}=0.00487 \pm 0.00005 \mathrm{mg} / \mathrm{mL}\right)$, AHT2 $\left(I C_{50}=0.00499 \pm 0.00007 \mathrm{mg} / \mathrm{mL}\right), D H T 2\left(I C_{50}=0.00499 \pm 0.00005 \mathrm{mg} / \mathrm{mL}\right)$ and $E H T 2$ $\left(I C_{50}=0.00667 \pm 0.00039 \mathrm{mg} / \mathrm{mL}\right)$ were more potent on free radical scavenging higher than all of groups. The ABTS ${ }^{+}$assay, at the Week 2 of all fertilizer groups were given with all solvent extraction including BHT1 $\left(I C_{50}=0.03191 \pm 0.00257 \mathrm{mg} / \mathrm{mL}\right)$, CHT1 $\left(I \mathrm{C}_{50}=0.03247 \pm 0.00044\right.$ $\mathrm{mg} / \mathrm{mL}), A H T 1\left(I C_{50}=0.03320 \pm 0.00120 \mathrm{mg} / \mathrm{mL}\right), E H T 1\left(I C_{50}=0.03342 \pm 0.00116 \mathrm{mg} / \mathrm{mL}\right)$ and AAT1 $\left(I C_{50}=0.03792 \pm 0.00076 \mathrm{mg} / \mathrm{mL}\right)$ showed free radical scavenging activity not different from standard substances, ascorbic acid $\left(I C_{50}=0.00699 \pm 0.00004 \mathrm{mg} / \mathrm{mL}\right)$ and Trolox ${ }^{\otimes}\left(I C_{50}\right.$ $=0.01594 \pm 0.00116 \mathrm{mg} / \mathrm{mL}$ ). Conclusion: The study was undertaken to investigate it's fertilizer use, harvest time and extraction method for biologically activities also chemical composition contents and their antioxidant potentials. Therefore, our data might be help to good cultivation and harvesting practice selection in order to produce better of mulberry leaf production. Key words: Fertilizer, Harvesting, Phytochemistry, Antioxidation, Mulberry leaves.
\end{abstract}

\section{INTRODUCTION}

In Thailand, the mulberry is widly cultivated within promotion and support by government agencies especially Sakolnakorn variety. Thai farmer used their leaves for feed silkworms and the fruits are eaten raw or processed as juice, mulberry fruit wine and supplementary food. Norteastern of Thailand, Thai rarul has been favorite bring them for a local cuisine called "Boiled chicken" indicated to folklore cooking wisdom which this will make the food useful and tasteful. ${ }^{1}$

Mulberry (Morus alba L.) is belonging to the family Moraceae, is a short-lived, fast-growing, small to medium sized mulberry tree, which grows to $10-20 \mathrm{~m}$ tall. The plant can grow in a wide range of climatic, topographical and soil conditions which can affect the chemical composition and nutritional status. ${ }^{2-4}$ The mulberry leaves have been widely used to produce various functional foods such as mulberry leaf carbonated beverages, health beverages and mulberry leaf tea. Phytochemical investigation has indicated that there are many active constituents such as flavonoids, alkaloids, phenolics, steroids, ${ }^{5}$ amino acids, simple phenylpropanoids ${ }^{6}$ and polysaccharides. $^{3}$ The plant has been used to treat various illnesses since ancient times. The herb was described as being able to eliminate cold and heat in the body, promote perspiration and have detoxifying properties. ${ }^{6}$ It has been exhibit multiple therapeutic effects

Cite this article: Chanhan P, Konsue A, Nammatra R. Effect of Agricultural Model of using Fertilizer, Harvesting Time and Extraction Method on Phytochemical Contents and Antioxidant Activities from Mulberry Leaves Grown in Maha Sarakham Province, Thailand. Pharmacog J. 2019;11(3):531-5. 
including anti-diabetic, anti-inflammation, anti-cancer effects, ${ }^{5}$ antihyperglycemic, anti-hyperlipidemia activities, ${ }^{3}$ hypoglycemic, antidepressant, antioxidant and hepatoprotective effects. ${ }^{4}$

Herbal preparation have gained good attention toward the treatment of various diseases on the globe. Phytopharmaceuticals have revealed the efficacy and toxicity associated with herbal agents and have become more popular among public. ${ }^{7}$ Traditional extraction methods including soxhlet appalatus extraction, heating reflux extraction and organic solvent maceration have some disadvantages. The effects of main operating extraction yields were investigated. The extraction method is an important factor for the use of plant active components. ${ }^{5}$ The free radical scavenging properties postulated to be as a result of the synergistic action of antioxidant compounds including carotenoids, flavonoids, moracins and others present in the mulberry leaves. Oxidative stress, which results from an improper balance between Reactive Oxygen Species (ROS) and their metabolites and antioxidant defence, is a factor in the pathogenesis of various diseases such as cardiovascular disorders, neurological conditions, Parkinson's disease, rheumatoid arthritis and ageing. ${ }^{8}$

However, though many literatures were reveal some biological activities, chemical compositions, cultivation and havesting, but there is no yet any report to the appropriately agricultural model in Thailand Farming. Therefore, the propose in this study were detemined to fertilizer use, time of harvesting and solvent extraction on phytochemical compositon and effect of antioxidant activities to appropriately agricultural selection which will be help to increase productivity.

\section{MATERIALS AND METHODS}

\section{Sample Collection}

The white mulberry (Variety: Sakolnakorn) were cultivated at the Experimental Farm of the New Innovation Excellence Center, Mahasarakham University, Maha Sarakham, Thailand. The plants were given to different fertilizer including chicken dung fertilizer, Urea fertilizer formula 46-0-0, chemical fertilizer formula 15-15-15 and mix of all (w:w:w;1:1:1) after trim of branch. The fresh leaves were harvested at Week 2 and Week 4 growing period. They were cleaned and dried at $60^{\circ} \mathrm{C}$ for $48 \mathrm{hr}$ in a hot air oven then powdered.

\section{Preparation of Extracts}

The aquoes extract was prepared by distilled water for $30 \mathrm{~min}$ at $60^{\circ} \mathrm{C}$ in sonication bath $(1: 10 \mathrm{w} / \mathrm{v})$. The ethanolic extracts were macerated with $50 \%$ ethanol and $95 \%$ ethanol for 7 days $(1: 5 \mathrm{w} / \mathrm{v})$. The residue powder was excluded by using filter papers. The filtrate was evaporated using by a rotary evaporator (Heidolph Laborota 4000, Germany) and freeze-dried to obtain dark brown extract. The extracts were kept in the fridge at $-4^{\circ} \mathrm{C}$ until be used.

\section{Total phenolic content assay}

Total phenolic content was determined according to a modified procedure. ${ }^{9}$ Sample $(100 \mu \mathrm{L})$ will be oxidized with $500 \mu \mathrm{L}$ of $0.2 \mathrm{~N}$ FolinCiocalteu's reagent and neutralized by adding $400 \mu \mathrm{L}$ of $7.5 \% \mathrm{Na}_{2} \mathrm{CO}_{3}$. The absorbance measured at $765 \mathrm{~nm}$ after mixed and incubated in room temperature for $30 \mathrm{~min}$. The results were expressed as gallic acid equivalents (mgGE/gExt).

\section{Total Flavonoid Content Assay}

Flavonoid content was estimated using the aluminum chloride colorimetric method. ${ }^{10}$ The extracts from recipe will be mixed with $100 \mu \mathrm{L}$ of $5 \%$ aluminum chloride (w/v), $400 \mu \mathrm{L}$ of $2.5 \% \mathrm{NaNO}_{2}$ After $5 \mathrm{~min}, 500 \mu \mathrm{L}$ of $5 \% \mathrm{AlCl}_{3}$. The mixture will be allowed to stand at room temperature for $10 \mathrm{~min}$. The solution was mixed $2,000 \mu \mathrm{L}$ distilled water. The results was measured at $415 \mathrm{~nm}$. The TFC was calculated from a standard quercetin equivalent (mgQE/gExt).

\section{DPPH free radical scavenging activity}

2,2-diphenyl-1-picrylhydrazy (DPPH) radical scavenging capacities of wheat extracts were estimated by the reduction of the reaction color between DPPH solution and sample extracts as previously described by prior method. ${ }^{11}$ DPPH was dissolved in ethanol to a $0.039 \mathrm{mg} / \mathrm{mL}$. The plant extract at various concentrations was diluted with distilled water to get sample solution. $100 \mu \mathrm{L}$ of the sample solution following which $900 \mu \mathrm{L} \mathrm{DPPH}(0.1 \mathrm{mM})$ working solution. After a $30 \mathrm{~min}$ reaction kept in the dark at ambient temperature then absorbance of the solution was measured at $515 \mathrm{~nm}$. In this study, will be used Trolox ${ }^{\circledR}$ and ascorbic acid as standard substances. Blanks were run in each assay. DPPH radical ability was expressed as $\mathrm{IC}_{50}(\mathrm{mg} / \mathrm{mL})$ and the inhibition percentage calculated using the following formula: DPPH scavenging activity $(\%)=\left(A_{0}-A_{1}\right) / A_{0} \times 100$ where $A_{0}$ is the absorbance of the control and $A_{1}$ is the absorbance of the sample.

\section{$\mathrm{ABTS}^{+}$Radical Scavenging Activity}

In ABTS assay, the plants extract will be allowed to react with $\mathrm{ABTS}^{+}$, a model stable free radical derived from 2,2-azinobis (3-ethylvenzothiazolin-6-sulphonic acid) $\left(\mathrm{ABTS}^{+}\right)$assay was performed. ${ }^{12}$ The $\mathrm{ABTS}^{+}$ $(900 \mu \mathrm{L})$ was added to the extracts $(100 \mu \mathrm{L})$ and thoroughly mixed. The mixture was held at room temperature for $6 \mathrm{~min}$ and absorbance was immediately measured at $734 \mathrm{~nm}$. Trolox ${ }^{\circledR}$ and ascorbic acid solution in $80 \%$ ethanol was prepared and assayed under the same conditions. ABTS scavenging ability was expressed as $\mathrm{IC}_{50}(\mathrm{mg} / \mathrm{mL})$ and the inhibition percentage calculated using the following formula: ABTS scavenging activity $(\%)=\left(A_{0}-A_{1}\right) / A_{0} \times 100$ where $A_{0}$ is the absorbance of the control and $A_{1}$ is the absorbance of the sample.

\section{Statistical Analysis}

All assays were expressed as mean \pm Standard Error of Mean (SEM) from three separate experiments $(n=3)$. Statistical analysis was carried out using One-Way Analysis of Variance (ANOVA) followed by Duncan's multiple range tests. Differences at $p<0.05$ were considered to be significant.

\section{RESULTS}

\section{Phytochemical Compositions Total Phenolic Contents}

As shown in Table 1, the plant were given extraction with 95\% ethanol, all of fertilizer and at Week 4 shown highest total phenolic contents, espectcially BET2 was high amount of TPC (124.444 $\pm 0.609 \mathrm{mgGE} / \mathrm{gExt})$ than DET2 (116.074 $\pm 0.588 \mathrm{mgGE} / \mathrm{gExt})$, AET2 (115.118 $\pm 0.567 \mathrm{mgGE} / \mathrm{gExt})$, CET $(85.741 \pm 0.937 \mathrm{mgGE} / \mathrm{gExt})$ and EET2 (75.639 $\pm 1.445 \mathrm{mgGE} / \mathrm{gExt})$ respectively. The harvest time, all of groups at the Week 4 were significantly higher than all of groups at the Week 2 .

\section{Total Flavonoid Contents}

As shown in Table 1, the DET1 (fertilizer formula 15-15-15, extraction with 95\% ethanol at the Week 2; 110.913 $\pm 3.208 \mathrm{mgQE} / \mathrm{gExt})$ showed highest total flavonoid contents highest amount than AET1 (88.398 \pm 2.905 $\mathrm{mgQE} / \mathrm{gExt})$, EHT (88.280 $\pm 1.171 \mathrm{mgQE} / \mathrm{gExt})$, BET $(80.860 \pm 2.009$ mgQE/gExt) and CET1 (72.663 $\pm 2.156 \mathrm{mgQE} / \mathrm{gExt})$ respectively. The harvest time, all of groups at the Week 2 were not different than all of groups at the Week 4 . 
Table 1: Phytochemical Composition Showed Total Phenolic Contents (TPC) and Total Flavonoid Contents (TFC) from Mulbery Leaf Extract.

\begin{tabular}{|c|c|c|c|c|c|}
\hline & \multirow{2}{*}{ Groups } & \multicolumn{2}{|c|}{ TPC (mgGE/gExt) } & \multicolumn{2}{|c|}{ TFC (mgQE/gExt) } \\
\hline & & Mean & Std. Error & Mean & Std. Error \\
\hline 1 & AAT1 & $1.951^{\mathrm{ab}}$ & \pm 0.118 & $36.378^{j}$ & \pm 0.464 \\
\hline 2 & BAT1 & $1.582^{\mathrm{ab}}$ & \pm 0.163 & $13.740^{\text {cd }}$ & \pm 0.419 \\
\hline 3 & CAT1 & $2.582^{\mathrm{abc}}$ & \pm 0.024 & $38.683^{1}$ & \pm 1.029 \\
\hline 4 & DAT1 & $1.747^{\mathrm{ab}}$ & \pm 0.051 & $31.783^{\mathrm{hi}}$ & \pm 1.553 \\
\hline 5 & EAT1 & $1.758^{\mathrm{ab}}$ & \pm 0.020 & $15.888^{\mathrm{d}}$ & \pm 0.068 \\
\hline 6 & AHT1 & $2.751^{\mathrm{bc}}$ & \pm 0.162 & $49.123^{\mathrm{m}}$ & \pm 0.847 \\
\hline 7 & BHT1 & $1.2441^{\mathrm{ab}}$ & \pm 0.013 & $60.533^{\mathrm{n}}$ & \pm 1.401 \\
\hline 8 & CHT1 & $2.3741^{\mathrm{bc}}$ & \pm 0.061 & $60.550^{\mathrm{n}}$ & \pm 0.397 \\
\hline 9 & DHT1 & $1.884 \mathrm{l}^{\mathrm{ab}}$ & \pm 0.020 & $41.515^{1}$ & \pm 0.997 \\
\hline 10 & EHT1 & $3.7141^{\mathrm{c}}$ & \pm 0.143 & $88.280^{q^{\sharp}}$ & \pm 1.171 \\
\hline 11 & AET1 & $0.401^{\mathrm{a}}$ & \pm 0.019 & $88.398^{q^{\sharp}}$ & \pm 2.905 \\
\hline 12 & BET1 & $0.302^{\mathrm{a}}$ & \pm 0.029 & $80.860^{\mathrm{p} \#}$ & \pm 2.009 \\
\hline 13 & CET1 & $0.352^{\mathrm{a}}$ & \pm 0.004 & $72.663^{\text {o\# }}$ & \pm 2.156 \\
\hline 14 & DET1 & $0.311^{\mathrm{a}}$ & \pm 0.015 & $110.913^{\text {rt }}$ & \pm 3.208 \\
\hline 15 & EET1 & $0.446^{\mathrm{a}}$ & \pm 0.010 & $75.270^{\circ}$ & \pm 1.657 \\
\hline 16 & AAT2 & $14.114^{\mathrm{d}}$ & \pm 0.594 & $7.935^{\mathrm{a}}$ & \pm 0.116 \\
\hline 17 & BAT2 & $15.059^{d}$ & \pm 0.387 & $9.730^{\mathrm{ab}}$ & \pm 0.126 \\
\hline 18 & CAT2 & $23.925^{g}$ & \pm 0.104 & $16.203^{\mathrm{de}}$ & \pm 0.221 \\
\hline 19 & DAT2 & $22.488^{\mathrm{g}}$ & \pm 0.490 & $11.895^{\mathrm{bc}}$ & \pm 0.147 \\
\hline 20 & EAT2 & $17.073^{\mathrm{e}}$ & \pm 0.746 & $11.288^{\mathrm{abc}}$ & \pm 0.719 \\
\hline 21 & AHT2 & $29.434^{\mathrm{i}}$ & \pm 1.035 & $25.025^{\mathrm{f}}$ & \pm 0.237 \\
\hline 22 & BHT2 & $26.769^{\mathrm{h}}$ & \pm 0.464 & $29.540^{\mathrm{gh}}$ & \pm 0.316 \\
\hline 23 & CHT2 & $28.157^{\mathrm{hi}}$ & \pm 1.553 & $32.320^{\mathrm{hi}}$ & \pm 0.372 \\
\hline 24 & DHT2 & $26.873^{\mathrm{h}}$ & 0.397 & $28.910^{\mathrm{gh}}$ & \pm 0.590 \\
\hline 25 & EHT2 & $19.375^{\mathrm{f}}$ & \pm 0.168 & $19.625^{\mathrm{e}}$ & \pm 0.173 \\
\hline 26 & AET2 & $115.118^{1 *}$ & \pm 0.567 & $32.483^{\mathrm{hi}}$ & \pm 0.896 \\
\hline 27 & BET2 & $124.444^{\mathrm{m} / \mathrm{t}}$ & \pm 0.610 & $42.170^{1}$ & \pm 0.621 \\
\hline 28 & CET2 & $85.741^{\mathrm{k} \#}$ & \pm 0.937 & $19.588^{e}$ & \pm 0.577 \\
\hline 29 & DET2 & $116.074^{1 *}$ & \pm 0.588 & $34.688^{i j}$ & \pm 0.197 \\
\hline 30 & EET2 & $75.639^{j \neq}$ & \pm 1.445 & $26.673^{\mathrm{fg}}$ & \pm 0.435 \\
\hline
\end{tabular}

Groups: The first capital were diffirent fertilizers; A was a control group, B was given with chicken dung fertilizer, $\mathrm{C}$ was given with Urea fertilizer formula 46-0-0, D was given with chemical fertilizer formula 15-15-15 and $\mathrm{E}$ was given with mix of all fertilizer (w:w:w;1:1:1). The second capital were different extraction methods; A was extracted with aquoes, B was extracted with $50 \%$ ethanol and C was extracted with $95 \%$ ethanol. The third capital were time of harvesting; T1 was harvested at Week 2 and T2 was harvested at Week 4. TPC was measured with gallic acid equivalents (mgGE/gExt). TFC was measured with quercetin equivalent (mgQE/gExt). Different letters indicated significantly difference at $p$-values less than 0.05 . \# ingradient contents as top of five from different groups.

\section{Antioxidant Activities}

\section{DPPH Free Radical Scavenging Activity}

As Table 2 shown in this study, DPPH free radical scavenging activity, standard substances, ascorbic acid and Trolox ${ }^{\circledR}$ were showed more potent than all of groups. The groups were given extraction with $95 \%$ ethanol,
Table 2: Antioxidant Activities Showed Inhibitory Concentration $\left(\mathrm{IC}_{50}\right)$ of different Extracts from Mulbery Leaves.

\begin{tabular}{|c|c|c|c|c|c|}
\hline & \multirow{2}{*}{ Groups } & \multicolumn{2}{|c|}{ DPPH $(\mathrm{mg} / \mathrm{mL})$} & \multicolumn{2}{|c|}{$\mathrm{ABTS}^{+}(\mathrm{mg} / \mathrm{mL})$} \\
\hline & & Mean & Std. Error & Mean & Std. Error \\
\hline 1 & AAT1 & $0.13681^{\mathrm{d}}$ & \pm 0.00091 & $0.03792^{\mathrm{a} *}$ & \pm 0.00076 \\
\hline 2 & BAT1 & $0.16073^{f}$ & \pm 0.00301 & $0.06137^{\mathrm{a}}$ & \pm 0.00187 \\
\hline 3 & CAT1 & $0.13874^{\mathrm{d}}$ & \pm 0.00171 & $0.03879^{\mathrm{a}}$ & \pm 0.00120 \\
\hline 4 & DAT1 & $0.11951^{\mathrm{d}}$ & \pm 0.00159 & $0.04175^{\mathrm{a}}$ & \pm 0.00022 \\
\hline 5 & EAT1 & $0.14014^{\mathrm{d}}$ & \pm 0.00144 & $0.05201^{\mathrm{a}}$ & \pm 0.00311 \\
\hline 6 & AHT1 & $0.07715^{\mathrm{b}}$ & \pm 0.00086 & $0.03320^{\mathrm{a*}}$ & \pm 0.00120 \\
\hline 7 & BHT1 & $0.15454^{\mathrm{e}}$ & \pm 0.00209 & $0.03191^{\mathrm{a} *}$ & \pm 0.00257 \\
\hline 8 & CHT1 & $0.13915^{\mathrm{d}}$ & \pm 0.00118 & $0.03247^{\mathrm{a} *}$ & \pm 0.00044 \\
\hline 9 & DHT1 & $0.14263^{\mathrm{d}}$ & \pm 0.00285 & $0.06647^{\mathrm{a}}$ & \pm 0.00040 \\
\hline 10 & EHT1 & $0.10621^{\mathrm{c}}$ & \pm 0.00125 & $0.03342^{\mathrm{a} *}$ & \pm 0.00116 \\
\hline 11 & AET1 & $0.23183^{\mathrm{i}}$ & \pm 0.02663 & $0.04570^{\mathrm{a}}$ & \pm 0.00096 \\
\hline 12 & BET1 & $0.23409^{i}$ & \pm 0.01890 & $0.05372^{\mathrm{a}}$ & \pm 0.00211 \\
\hline 13 & CET1 & $0.27159^{k}$ & \pm 0.02507 & $0.06922^{\mathrm{a}}$ & \pm 0.00060 \\
\hline 14 & DET1 & $0.47942^{1}$ & \pm 0.01444 & $0.07247^{\mathrm{b}}$ & \pm 0.00108 \\
\hline 15 & EET1 & $0.50773^{1}$ & \pm 0.04121 & $0.08160^{c}$ & \pm 0.00102 \\
\hline 16 & AAT2 & $0.28296^{k}$ & \pm 0.00118 & $0.79605^{j}$ & \pm 0.01583 \\
\hline 17 & BAT2 & 0.26324 & \pm 0.00067 & $0.67562^{\mathrm{i}}$ & \pm 0.00693 \\
\hline 18 & CAT2 & $0.25276^{j}$ & \pm 0.01145 & $0.41878^{e}$ & \pm 0.01293 \\
\hline 19 & DAT2 & $0.14529^{d}$ & \pm 0.00123 & $0.36976^{\mathrm{d}}$ & \pm 0.02510 \\
\hline 20 & EAT2 & $0.26149^{j}$ & \pm 0.00335 & $0.48170^{\mathrm{g}}$ & \pm 0.01750 \\
\hline 21 & AHT2 & $0.00499^{\mathrm{a} *}$ & \pm 0.00007 & $0.35238^{\mathrm{d}}$ & \pm 0.02437 \\
\hline 22 & ВHT2 & $0.00487^{\mathrm{a} *}$ & \pm 0.00005 & $0.44635^{f}$ & \pm 0.01734 \\
\hline 23 & CHT2 & $0.00459^{\mathrm{a} *}$ & \pm 0.00001 & $0.37508^{\mathrm{d}}$ & \pm 0.00592 \\
\hline 24 & DHT2 & $0.00499^{\mathrm{a} *}$ & \pm 0.00005 & $0.45111^{\mathrm{f}}$ & \pm 0.01218 \\
\hline 25 & ЕHT2 & $0.00667^{\mathrm{a} *}$ & \pm 0.00039 & $0.61084^{\mathrm{h}}$ & \pm 0.02278 \\
\hline 26 & AET2 & $0.21447^{\mathrm{h}}$ & \pm 0.01491 & $0.65082^{\mathrm{h}}$ & \pm 0.02265 \\
\hline 27 & BET2 & $0.14216^{\mathrm{d}}$ & \pm 0.00497 & $0.67521^{\mathrm{i}}$ & \pm 0.02154 \\
\hline 28 & CET2 & $0.18630^{\mathrm{g}}$ & \pm 0.02010 & $0.83239^{j}$ & \pm 0.07338 \\
\hline 29 & DET2 & $0.12485^{d}$ & \pm 0.00218 & $0.90744^{\mathrm{k}}$ & \pm 0.03162 \\
\hline 30 & EET2 & $0.18622^{\mathrm{g}}$ & \pm 0.00314 & $1.30769^{1}$ & \pm 0.03071 \\
\hline 31 & ascorbic acid & $0.00018^{\mathrm{a}}$ & \pm 0.00001 & $0.00699^{\mathrm{a}}$ & \pm 0.00004 \\
\hline 32 & trolox $^{\circledR}$ & $0.05156^{\mathrm{b}}$ & \pm 0.00016 & $0.01594^{\mathrm{a}}$ & \pm 0.00017 \\
\hline
\end{tabular}

Groups: The first capital were diffirent fertilizers; A was a control group, B was given with chicken dung fertilizer, $\mathrm{C}$ was given with Urea fertilizer formula 46-0-0, D was given with chemical fertilizer formula 15-15-15 and $\mathrm{E}$ was given with mix of all fertilizer (w:w:w;1:1:1). The second capital were different extraction methods; A was extracted with aquoes, B was extracted with $50 \%$ ethanol and C was extracted with $95 \%$ ethanol. The third capital were time of harvesting; T1 was harvested at Week 2 and T2 was harvested at Week 4. DPPH radical scavenging and $\mathrm{ABTS}^{+}$assay were used ascorbic acid and trolox ${ }^{\circledR}$ as standard substances. Different letters indicated significantly difference at $p$-values less than 0.05 . \# influence of free radical scavenging as top of five from different groups.

all of fertilizer at the Week 4 including $\mathrm{CHT} 2\left(\mathrm{IC}_{50}=0.00459 \pm 0.00001\right.$ $\mathrm{mg} / \mathrm{mL})$, BHT2 $\quad\left(\mathrm{IC}_{50}=0.00487 \pm 0.00005 \mathrm{mg} / \mathrm{mL}\right), \quad$ AHT2 $\quad\left(\mathrm{IC}_{50}\right.$ $=0.00499 \pm 0.00007 \mathrm{mg} / \mathrm{mL})$, DHT2 $\left(\mathrm{IC}_{50}=0.00499 \pm 0.00005 \mathrm{mg} / \mathrm{mL}\right)$ and EHT2 $\left(\mathrm{IC}_{50}=0.00667 \pm 0.00039 \mathrm{mg} / \mathrm{mL}\right)$ were more potent on free radical scavenging higher than all of groups. 


\section{$\mathrm{ABTS}^{+}$Radical Scavenging Activity}

As Table 2 shown by using $\mathrm{ABTS}^{+}$assay, at the Week 2 of all fertilizer groups were given with all solvent extraction including $\mathrm{BHT} 1 \mathrm{IC}_{50}$ $=0.03191 \pm 0.00257 \mathrm{mg} / \mathrm{mL})$, CHT1 $\left(\mathrm{IC}_{50}=0.03247 \pm 0.00044 \mathrm{mg} / \mathrm{mL}\right)$, AHT1 $\left(\mathrm{IC}_{50}=0.03320 \pm 0.00120 \mathrm{mg} / \mathrm{mL}\right)$, EHT1 $\left(\mathrm{IC}_{50}=0.03342 \pm 0.00116\right.$ $\mathrm{mg} / \mathrm{mL})$ and AAT1 $\left(\mathrm{IC}_{50}=0.03792 \pm 0.00076 \mathrm{mg} / \mathrm{mL}\right)$ showed free radical scavenging activity not different from standard substances, ascorbic acid $\left(\mathrm{IC}_{50}=0.00699 \pm 0.00004 \mathrm{mg} / \mathrm{mL}\right)$ and Trolox $\AA\left(\mathrm{IC}_{50}=0.01594 \pm 0.00116\right.$ $\mathrm{mg} / \mathrm{mL}$ ). All groups of the Week 2 were significantly free radical scavenging acitivity on $\mathrm{IC}_{50}$ less than all the groups of Week 4 .

\section{DISCUSSION}

Mulberry leaves contain a wide range of bioactive compounds, such as flavonoid and phenolic compound contents of white mulberry leaves depended on the harvest time which are responsible for beneficial effects on human health. ${ }^{13}$ The mulberry leaves have been extensively investigated for their various health benefits, including antioxidative, hypolipidemic, antihyperglycemic and antiatherogenic effects.

This studies have indicated that mulberry leaves exhibited significant scavenging effects on free radicals both $\mathrm{DPPH}$ and $\mathrm{ABTS}^{+}$which protected low-density lipoprotein against oxidative damage. The reports suggested that polyphenols and flavonoids present in mulberry contribute to these health benefits. ${ }^{14}$ In the present study, the free radical scavenging activities, phenolic compound and flavonoid contents of the extract were significantly different according to the fertilizers, harvest times and extraction methods. The phenolic compound contents by $95 \%$ ethanolic extraction related with harvesting time. The study showed that Week4 were highest phenolic compound contents exert than other method, particular environment and has a direct bearing on the composition of the plants found there. ${ }^{15}$ The methods applied in this study considered the antioxidant properties of the mulberry extract as determined by different group testing methods. ${ }^{16}$ It has been reported that mulberry contains a lot of bioactive compound, polysaccharides, but in this study did not extracted on a Box-Behnken design, polysacharide function isolation. It is well known that the biological functions including antioxidant activity of polysaccharides are intimately related to their structure features such as chemical components, molecular weight, monosaccharide composition and glycosidic linkage. A comprehensive study of purification, characterization and antioxidant activities of mulberry leaves will provide useful information on the relationship between antioxidant activity and structure features. ${ }^{17-18}$ Some report was reveal that this in animal model can be used in functional food studies, where information on the absorption and bioavailability of dietary antioxidants is still limited. The reported mechanisms for the absorption of flavonoids probably due to the presence of antioxidants with higher glucose moieties in the extract. ${ }^{19}$

Therefore, we report here the fertilizer use, harvesting time and extraction were applied to optimize conditions on phytochemical content and antioxidation activity and the resulting extraction conditions were used to prepare cultivation through harvest and extraction method precipitation. Mulberry leaves harvested on Week 4, ethanolic maceration had the highest total phenolic contents. On the other hand, total flavonoid contents had highest on Week 2 by using hydroethanolic extraction. It considered to be a better model concerning phenolic and flavonoid contents on antioxidant activity, respectively. ${ }^{20}$ These methods may not produce plants with the highest levels of the targeted functional components and so some modifications of the agricultural model may be necessary. Based on the results of the current study, formulation of fertilizer, time of harvesting and method of extraction appear to be valid indicators for determining the best practice model to obtain the highest amounts of each targeted functional component. ${ }^{21}$
However, the current study was undertaken to investigate its fertilizer use, harvest time and extraction method for biologically activities also chemical constituent contents and antioxidant potentials. In addition, isolation, purification and identification of active compounds obtained from mulberry leaves were also researched.

\section{CONCLUSION}

This study showed that the mulberry leaves form Sakolnakorn cultivar were nutritionally rich, highest total flavonoid and phenolic compound contents were found in the leaves. Our results might be help to select the good cultivation and harvesting practice in order to produce better also quantitative or/and qualitative mulberry leaf production.

\section{ACKNOWLEDGEMENT}

The study was partially financial supported by the Development Research Division, Mahasarakham University, Maha Sarakham, Thailand and National Research Council of Thailand (NRCT) Bangkok, Thailand.

\section{CONFLICT OF INTEREST}

There are no conflicts of interest.

\section{ABBREVIATIONS}

TPC: Total phenolic compounds; TFC: Total flavonoid contents; DPPH: 2,2-diphenyl-1-picrylhydrazy assay; ABTS+: 2,2 -azinobis-(3-ethylbenzothiazoline-6-sulphonate) assay.

Groups: The first capital were diffirent fertilizers; A was a control group, $\mathrm{B}$ was given with chicken dung fertilizer, $\mathrm{C}$ was given with Urea fertilizer formula 46-0-0, D was given with chemical fertilizer formula 15-15-15 and $\mathrm{E}$ was given with mix of all fertilizer (w:w:w;1:1:1). The second capital were different extraction methods; A was extracted with aquoes, B was extracted with $50 \%$ ethanol and C was extracted with $95 \%$ ethanol. The third capital were time of harvesting; T1 was harvested at Week 2 and $\mathrm{T} 2$ was harvested at Week 4.

\section{REFERENCES}

1. Office of the Royal Development Projects Board. Sakolnakorn variety mulberry and NangTouy variety silkworms. 2Ed. Office of the Royal Development Projects Board; Bangkok, Thailand. 2012

2. Khyade VB. Antioxidant activity and phenolic compounds of mulberry, Morus alba (L.) (Variety: Baramatiwali). J Med Plants Stud. 2016;4(1):04-7.

3. Thirugnanasambandham K, Sivakumar V, Prakash MJ. Microwave assisted extraction of polysaccharides from mulberry leaves. Int J Biol Macromol. $2015 ; 72: 1-5$

4. Yang Z, Wang Y, Zhang Y. Bioassay-guided screening and isolation of a-glucosidase and tyrosinase inhibitors from leaves of Morus alba. Food Chem. 2012;131(2):617-25

5. Zhang DY, Wan Y, Xu JY, Wu GH, Li L, Yao XH. Ultrasound extraction of polysaccharides from mulberry leaves and their effect on enhancing antioxidant activity. Carbohydr Polym. 2016;137:473-9

6. Tian S, Tang M, Zhao B. Current anti-diabetes mechanisms and clinical trials using Morus alba L. J Tradit Chin Med. 2016;3(1):3-8.

7. Banu S, Jabir NR, Manjunath NC, Khan MS, Ashraf GM, Kamal MA et al. Reduction of post-prandial hyperglycemia by mulberry tea in type-2 diabetes patients. Saudi J Biol Sci. 2015;22(1):32-6

8. Andallu B, Shankaran M, Ullagaddi R, lyer S. In vitro free radical scavenging and in vivo antioxidant potential of mulberry (Morus indica L.) leaves. J Herb Med. 2014;4(1):10-7.

9. Singleton VL, Orthofer R, Lamuela-Raventos RM. Analysis of total phenols and other oxidation substrates and antioxidants by means of Folin-Ciocalteu reagent. Meth Enzymol. 1999;299:152-78.

10. Chang C, Yang M, Wen H, Chern J. Estimation of total flavonoid content in propolis by two complementary colorimetric methods. J Food Drug Anal. 2002;10(3):178-82.

11. Ursini F, Mairorino M, Morazzoni P, Roveri A, Pifferi G. Anovel antioxidant flavonoid (IdB 1031) affecting molecular mechanisms of cellular activation. Free Rad Biol Med.1994;16(5):547-53. 
12. Long LH, Halliwell B. Oxidation and generation of hydrogen peroxide by thiol compounds in commonly used cell culture media. Biochem Biophys Res Commun. 2001;286(5):991-4.

13. Levickiene D, Jariene E, Gajewski M, Danilcenko H, Vaitkeviciene N, Przybył JL, et al. Influence of harvest time on biologically active compounds and the antioxidant activity in leaves of Mulberry grown in Lithuania. Not Bot Horti Agrobo. 2017;45(2):431-6.

14. Chang LW, Juang LJ, Wang BS, Wang MY, Tai HM, Hung WJ, Chen YJ, Huang MH. Antioxidant and anti tyrosinase activity of mulberry (Morus alba L.) twigs and root bark. Food Chem Toxicol. 2011;49(4):785-90.

15. Kim DS, Kang YM, Jin WY, Sung1YY, Choi G, Kim HK. Antioxidant activities and polyphenol content of Morus alba leaf extracts collected from varying regions. Biomed Rep. 2014;2(5):675-80
16. Roy LG, Arabshahi-Delouee S, Urooj A. Antioxidant efficacy of Mulberry (Morus Indica L.) leaves extract and powder in edible oil. Int J Food Prop. 2010;13(1):1-9.

17. Yuan $\mathrm{Q}$, Xie $Y$, Wang W, Yan $Y$, Ye H, Jabbar $S$, et al. Extraction optimization, characterization and antioxidant activity in vitro of polysaccharides from mulberry (Morus alba L.) leaves. Carbohydr Polym. 2015;128:52-62.

18. Ying Z, Han X, Li J. Ultrasound-assisted extraction of polysaccharides from mulberry leaves. Food Chem. 2011;127(3):1273-9.

19. Lee CY, Sim SM, Cheng HM. Systemic absorption of antioxidants from mulberry (Morus alba L) leaf extracts using an in situ rat intestinal preparation. Nutr Res. 2007;27(8):492-7.

20. Zou Y, Liao S, Shen W, Liu F, Tang C, Chen CY, et al. Phenolics and antioxidant activity of mulberry leaves depend on cultivar and harvest month in southern china. Int J Mol Sci. 2012;13(12):16544-53.

\section{GRAPHICAL ABSTRACT}

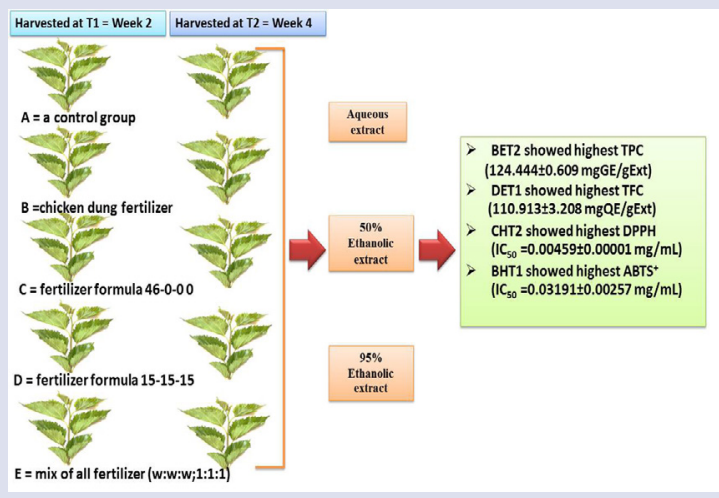

\section{SUMMARY}

- This study showed that the mulberry leaves form Sakolnakorn cultivar were nutritionally rich, highest total flavonoid and phenolic compound contents were found in the leaves.

\section{ABOUT AUTHORS}

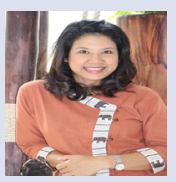

Rachanee Nammatra is an Assistant Professor at Mahasarakham University, Biodiversity Program, Walai Rukhavej Botanical Research Institute. Her research interests are on plant diversity and ecology, agricultural management, and natural herb tea products.

Cite this article: Chanhan P, Konsue A, Nammatra R. Effect of Agricultural Model of using Fertilizer, Harvesting Time and Extraction Method on Phytochemical Contents and Antioxidant Activities from Mulberry Leaves Grown in Maha Sarakham Province, Thailand. Pharmacog J. 2019;11(3):531-5. 